\title{
Short Communication: The prevalence and species of root-knot nematode which infect on potato seed in Central Java, Indonesia
}

\author{
MUTALA'LIAH ${ }^{1, \vartheta}$, SIWI INDARTI ${ }^{1,2, \vee v}$, ARIF WIBOWO ${ }^{1}$ \\ ${ }^{1}$ Department of Plant Pests and Diseases, Faculty of Agriculture, Universitas Gadjah Mada, Jl. Flora No.1 Bulaksumur, Sleman 55282, Yogyakarta, \\ Indonesia, Tel.: +62-274-523064, "email: mutalaliah@mail.ugm.ac.id, "vv siwi.indarti@ugm.ac.id \\ ${ }^{2}$ Agrotechnology Innovation Centre, Universitas Gadjah Mada, Kalitirto, Berbah, Sleman, Yogyakarta 55573 Indonesia, Telp.: +62-274-497717
}

Manuscript received: 3 July 2018. Revision accepted: 2 December 2018.

\begin{abstract}
Mutala'liah, Indarti S, Wibowo A. 2019. Short Communication: The prevalence and species of root-knot nematode which infect on potato seed in Central Java, Indonesia. Biodiversitas 20: 11-16. Root-knot nematodes are considered as one of the most destructive pathogens of potatoes, especially on tuber seed. Infected potato seed will cause tuber malformation and the most important thing is as the main spreading source of Meloidogyne spp. The objective of this research was to know the prevalence and identify the species of root-knot nematode which attack the potato seed in four sub-districts of potato production centre in Central Java, Indonesia. Molecular and morphological identification was conducted for the nematode species identification. PCR assay using MIG primer to detect three tropical root-knot nematodes followed by sequencing was conducted for molecular detection, while the perennial pattern was conducted for morphological detection. Results showed that root-knot nematodes on potato seed were generally distributed in Central Java with the prevalence percentage between $14.28-88.23 \%$ on the three from four sampling area. The molecular and morphological identification show that species of root-knot nematodes identified on potato seeds were Meloidogyne javanica, M. incognita, and M. arenaria.
\end{abstract}

Keywords: Meloidogyne, potato, seed tuber, species

\section{INTRODUCTION}

Root-knot nematodes (Meloidogyne spp.) are major pathogens of vegetables throughout the world and impacting both the quantity and quality of marketable yields, including on potato (Solanum tuberosum). The specific symptom of Meloidogyne spp. is root galls. It also cause another symptoms like chlorosis and stunted growth (Ye et al. 2015). Meloidogyne spp. is the most significantly impact on vegetable crops because it can be as a tuber and field borne pathogens (Coyne et al. 2018). Meloidogyne spp. are polyphagous nematodes that distributed worldwide. The highest impact is in the tropical region because of its favorable condition (Perry et al. 2009). In Indonesia, potato is one of the valuable horticultural commodities which is nowadays are attacked by Meloidogyne spp. The infection of this nematode on the potato tuber had also been reported in Argentina, Brazil, Japan, Libya, Zimbabwe, Saudi Arabia and Turkey (Vovlas et al. 2005).

Meloidogyne spp. can severely damage and cause a significant loss on potato depends on the nematode species (Vovlas et al. 2005). There were six species of Meloidogyne, i.e., Meloidogyne chitwoodi, M. fallax, M. hapla, $M$. arenaria, $M$. incognita, and $M$. javanica. In the colder climates, M. chitwoodi, M. fallax and M. hapla are causing a major problem, whereas $M$. arenaria, $M$. incognita, and $M$. javanica are in the warmer climates (Vovlas et al. 2005; Onkendi and Moleleki 2013). M. incognita is the most commonly found and causes loss until
80\% (Devi and Kumari 2014), while in Brazil, M. javanica was the major species which found in infected potato at about 97.8\% (Medina et al. 2017). In Tasmania, Australia, M. hapla and M. fallax caused serious problem on potato tuber. However, the most significant damage was caused by $M$. fallax (Hay et al. 2016) Another report of infectious potato tuber in Belgium, Ireland, Netherlands, Portugal, United Kingdom, Chile, and United states was caused by M. minor (Wesemael et al. 2014). In Asia, especially South China, some species of Meloidogyne (M. incognita, $M$. enterolobii and $M$. javanica not only caused significant losses on potato tuber, but also have serious problem on ornamental plant and fruit trees (Hu et al. 2011).

Meloidogyne spp.' infection on potato tuber in Indonesia was first reported in Ngablak, Magelang, Central Java in 2014. Almost $97 \%$ of fields were infested by Meloidogyne spp. (Suri and Jayasinghe 2014). Infected potato tuber caused some galls in the surface of the tuber. Females of Meloidogyne spp. with transparent color appeared on the flesh of tuber. It may cause blisters form on the tuber and make it unmarketable. More importantly, the infected seed tuber can facilitate this nematode's dissemination into new areas (Vovlas et al. 2005).

Central Java, Indonesia is the center of potato plantation. However, there was no report either about infectious tuber caused by Meloidogyne spp. or the species of this nematode. Therefore, the objective of this research was to examine the prevalence of Meloidogyne spp. that attacked potato seed and identify the species diversity of 
Meloidogyne spp. in the potato production area in Central Java, Indonesia.

\section{MATERIALS AND METHODS}

\section{Root-knot nematode distribution}

Survey was conducted in four potato producing areas in Central Java, i.e., Ngablak Sub-district (Magelang District), Kledung Sub-district (Temanggung District), Kejajar Subdistrict (Wonosobo District), and Pejawaran Sub-district (Banjarnegara District) from January until May 2015. Cluster sampling technique was carried out to determine the exact amount of the farmer's warehouse samples from each sub-district. The total number of farmers in four subdistrict was 1935, consisted of 1250 farmers in Kejajar (Personal communication with field officer 2015), 335 farmers in Ngablak (Personal communication with field officer 2015), 200 farmers in Pejawaran (Personal communication with field officer 2015), and 150 farmers in Kledung (Personal communication with agriculture institution 2015). The total number of sample was determined by the population and precision (10\%) which was 95 farmers or $5 \%$ from each sub-district, consisted of 17 farmers in Ngablak, 8 farmers in Kledung, 60 farmers in Kejajar and 10 farmers in Pejawaran. The data were analyzed according to the prevalence of nematodes. The frequency of the nematode was determined from the relationship between the numbers of sample where the nematode observed then divided by the total number of samples taken, and multiplied by 100 to express as the percentage of the prevalence (Sawadogo et al. 2009).

\section{Molecular identification}

Sampling for species identification was taken by purposive sampling technique from each sub-district. Only the potato which infected by Meloidogyne spp. would proceed for further species identification. CTAB method (Subandiyah 2003) was used for DNA extraction using 30 females of Meloidogyne spp. from each area then examined by PCR. The PCR program for MIG primer (Table 1) was $2 \mathrm{~min}$ at $94^{\circ} \mathrm{C}$ followed by 35 cycles of $30 \mathrm{~s}$ at $94^{\circ} \mathrm{C}, 30 \mathrm{~s}$ at $54^{\circ} \mathrm{C}$ as the annealing temperature and $1 \mathrm{~min}$ at $72^{\circ} \mathrm{C}$ (Zijlstra et al. 2000). Samples for the sequencing process was sent to Bioscience Singapore, then analyzed by Bioedit program to matched the DNA sample with DNA data in Gen Bank. Phylogenetic tree was made by neighbor-joining method (MEGA 6.06) to determine the similarity of each sample with the species of Meloidogyne that was listed in GenBank.

\section{Morphological identification}

Morphological identification for Meloidogyne spp. was based on the perennial pattern of female's posterior. Perennial pattern was the proper manner for morphological detection on Meloidogyne spp. because it is easy to obtain from the infected plant and it tends to be stable from the environmental changes (Eisenbeck 1985). Five female nematodes were collected from each sub-district for singly identification. This step was carried out to observe the existence of other minor species that could not be amplified in the molecular identification. Female Meloidogyne spp. was isolated from the infected tuber and placed on the slide glass under a stereoscopic microscope. An incision was made by using a scalpel in the middle of the female body to cut the cuticle into half equatorially. The posterior region consisting of the perennial pattern was carefully cut off and trimmed. The perennial pattern was gently brushed using alcohol to remove any attached debris (Singh 2009). The perennial pattern was captured by Optilab which was connected to the microscope Olympus $\mathrm{BH} 2$ by 400 times magnification.

\section{RESULTS AND DISCUSSION}

\section{The prevalence of Meloidogyne spp.}

Meloidogyne spp. was considered as one of the most impact yield losses both quality and quantity of the postharvest product, especially on potato. Potato tuber which was infected by Meloidogyne spp. had malformation on the outer surface of tuber (Figure 1.A) caused by some galls that released from nematode's infection. The appearance of the tuber was worst so it would be decreasing the quality of tuber and make tuber unmarketable. On the other hand, it was descending the postharvest quantity because the galls inhibit nutrition and water uptake, so that potato tuber was poorly developed. Infected potato tuber caused by Meloidogyne spp. was obtained from each sub-district in Central Java. The female nematode and egg mass were shown in the flesh of tuber. An egg mass of Meloidogyne spp. usually stick on the posterior region of female nematodes with the brownish color that appeared on the flesh of tuber (Figure 1.B). The female nematode was a little bit difficult to see because it had the same color with the flesh of tuber. The female nematode usually looks grouping on the flesh of tuber but sometimes it also looks singly (Figure 1.C).

Table 1. Primer identification of Meloidogyne spp.

\begin{tabular}{lllll}
\hline Species & $\begin{array}{l}\text { Primer } \\
\text { code }\end{array}$ & Sekuen 5'-3, & $\begin{array}{l}\text { DNA target } \\
(\text { bp })\end{array}$ & Source \\
\hline $\begin{array}{l}\text { Meloidogyne incognita, } \\
\text { M. javanica, } \text { M. } \text { arenaria }\end{array}$ & MIGF & ACACAGGGGAAAGTTTGCCA & 500 & Qiu et al. (2006) \\
\hline
\end{tabular}




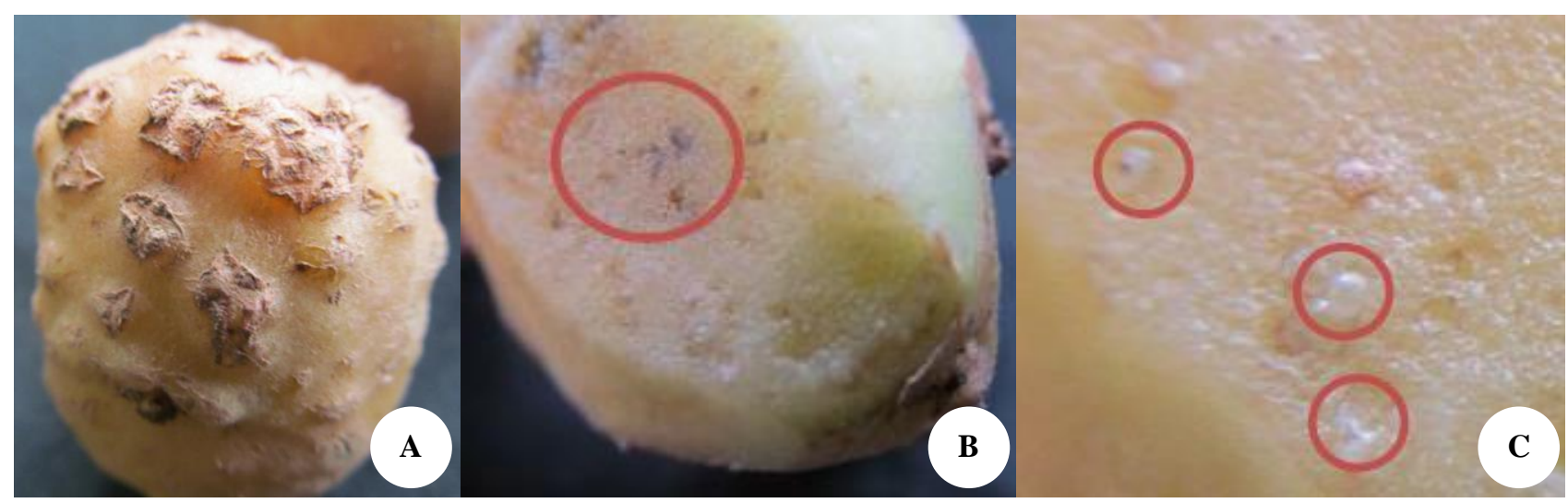

Figure 1. A. Potato seed malformation was caused by Meloidogyne spp. B. Egg mass of Meloidogyne spp., C. Female of Meloidogyne spp.

Table 2. Prevalence percentage of infected potato seed in Central Java, Indonesia

\begin{tabular}{llccl}
\hline Sub-district & District & $\begin{array}{c}\text { Farmer's } \\
\text { warehouse } \\
\text { samples }\end{array}$ & $\begin{array}{c}\text { Number } \\
\text { of } \\
\text { infectious } \\
\text { sample }\end{array}$ & $\%$ \\
\hline Ngablak & Magelang & 17 & 15 & 88.23 \\
Kledung & Temanggung & 8 & 5 & 62.50 \\
Kejajar & Wonosobo & 35 & 5 & 14.28 \\
Pejawaran & Banjarnegara & 10 & 0 & 0 \\
Total & & 70 & 25 & 35.71 \\
\hline
\end{tabular}

The survey results showed that Meloidogyne spp.' infection only presented in three sub-districts: Ngablak, Kledung, and Kejajar. Meanwhile, infectious potato by Meloidogyne spp. was not found in Pejawaran. The highest percentage of prevalence was in Ngablak (88.23\%) then followed by Kledung $(62.50 \%)$ and the least presence was in Kejajar which account for $14.28 \%$ (Table 2). The number of total sample in Kejajar was reduced because from 60 farmers, there were only 35 farmers that had potatoes in their warehouse at the sampling time.

The incidence of Meloidogyne spp. infection was influenced by the geographical factors of each area. Ngablak is located in Magelang District at 1293 meter above sea level (m asl) (Pemkab Magelang 2015), with temperature of $20-27^{\circ} \mathrm{C}$ and the soil type is andosols (Pemda Ngablak 2015). Kledung is located in Temanggung District at $1138 \mathrm{~m}$ asl, the temperature $20-30^{\circ} \mathrm{C}$ and the soil type is andosols (Pemkab Temanggung 2015). Kejajar is located in Wonosobo District at $1378-2250 \mathrm{~m}$ asl, the temperature $12-21{ }^{\circ} \mathrm{C}$ in the afternoon and $5-9{ }^{\circ} \mathrm{C}$ in the night. The soil type of this district is andosols (Pemkab Wonosobo 2015). Pejawaran is located in Banjarnegara District at more than $1700 \mathrm{~m}$ asl (Taher et al. 2012). The temperature and the soil type in Pejawaran are the same with Kejajar (NAWASIS 2010).

Based on that geographic information data, the infection incidence of Meloidogyne spp. was found in the area between 1100-1300 $\mathrm{m}$ asl and which also related to the optimum temperature for Meloidogyne spp. The temperature in Ngablak and Kledungs is suitable for Meloidogyne spp.'s development. Therefore the percentage of infection incidence was very high. In Kejajar, distribution infection only found in 5 areas located approximately at $1300 \mathrm{~m}$ asl, but it was not found in some areas above $1300 \mathrm{~m}$ asl. Likewise in Pejawaran, the infection incidence of Meloidogyne spp. on potato tuber was not found. It was caused by its location as the highest between all observed sampling areas, so that the temperatures also lower than others. Meloidogyne spp. cannot well develop in the cold temperature. The optimum development temperature for $M$. javanica and $M$. arenaria was $28^{\circ} \mathrm{C}$, whereas $M$. incognita was 25 or $30^{\circ} \mathrm{C}$. In the lowest temperature, $M$. javanica failed to reproduce egg (Bridge and Starr 2007; Perry et al. 2009).

In addition, another factor that influenced the infection incidence was the soil type. All of the surveyed areas had andosols soil type. Andosols soil type is volcanic soil type that good for agriculture. Besides that, andosols also have good aeration (Bowman and Arts 2001), thus it was easier for nematode migration. Nematode migration was decreased when the clay proportion of soil was up to $30 \%$ (Prot 1977), whereas in the sandy soil type, nematode can migrate until $75 \mathrm{~cm}$ for about nine days (Netscher and Sikora 1990). It was also in line with Archidona-Yuste et al. (2018), M. incognita has a high positive correlation with sandy loam soils, whereas it has a negative correlation with silt and clay (Asif et al. 2015). Sandy soil texture can facilitate $\mathrm{J} 2$ to penetrate the roots, thus the gall and egg mass were significantly increase in this soil type (Kim et al. 2017). Furthermore, potato infection caused by Meloidogyne spp. had high intensity in dry seasons harvesting (Private communication), whereas this research was taken on rainy season harvesting. Considering the percentage of infection incidence result in Central Java on rainy seasons harvesting, it could increase if the survey is taken in dry seasons harvesting. This result was also confirmed by Karajeh and Mohawesh (2016), root galling index and nematode population was higher at 80 and $100 \%$ irrigated than 20, 40 and $60 \%$. 


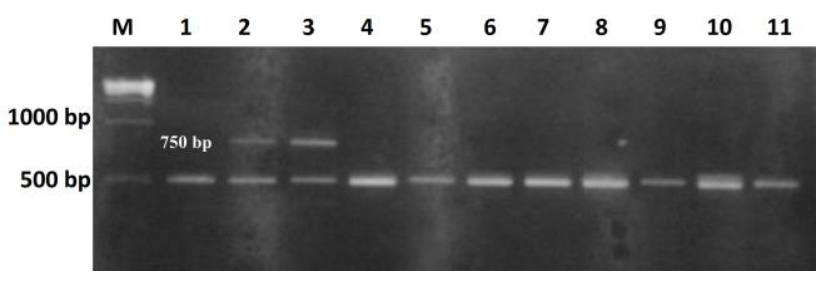

Figure 2. Amplification band used MIGF/MIGR primer. M: $1 \mathrm{~kb}$ DNA Ladder (Vivantis), Samples (1-11), 1-4: Ngablak samples, 5-7: Kejajar samples, 8-11: Kledung sample

\section{Molecular identification}

MIG primer was used for molecular identification of three species of Meloidogyne i.e., Meloidogyne incognita, M. Javanica, and M. arenaria. Qiu et al. (2006) had shown that MIG primer would detect $M$. incognita, $M$. javanica and $M$. arenaria on 500 bp. All samples produced amplicons on $500 \mathrm{bp}$; however, sample number 2 and 3 (sample from Ngablak) also amplified on another band, i.e., $750 \mathrm{bp}$ (Figure 2). This was a new result appeared on the visualization of PCR using MIG primer that should be only appeared on $500 \mathrm{bp}$.

The molecular identification using MIG primer on this research showed a variation on the amplification products with the study of Qiu et al. (2006). There were two types of amplicons, i.e., $500 \mathrm{bp}$ and $750 \mathrm{bp}$, whereas in a study by Qiu et al. (2006), the MIG primer amplified and produced only a single band on $500 \mathrm{bp}$ for the three species of Meloidogyne spp. (M. incognita, M. javanica, and $M$. arenaria). The different result might be caused by the different PCR program (Zijlstra et al. 2000) used on this study. Therefore, the DNA band showed the differences.

The sequencing results can identify the nematodes species of the amplicons products. The phylogenetic tree (Figure 3) showed that the sample amplicons on $500 \mathrm{bp}$ from all samples was closely related with $M$. javanica with the bootstrap value: 94 . Samples on 750 bp were closely related with $M$. incognita with the bootstrap value: 83 .
From this analysis, it can be inferred that only one species of Meloidogyne found in Kejajar and Kledung, i.e., M. javanica. On the other hand, there were two species of Meloidogyne found in Ngablak, i.e., M. javanica and M. incognita.

\section{Morphological identification}

Morphological identification of Meloidogyne spp. was conducted using the perennial pattern on five female nematodes in each sub-district. Morphological identification was used for supporting the molecular identification. Morphological identification of Meloidogyne spp. was difficult to distinguish because their perennial pattern look like similar (Oliveira et al. 2011). Based on the perennial pattern, there were two species of Meloidogyne found in Ngablak, i.e. M. javanica (Figure 4.A) and $M$. incognita (Figure 4.B). Both Kejajar and Kledung were found only one different species of Meloidogyne. In Kejajar, the Meloidogyne species was M. arenaria (Figure 4.C), whereas in Kledung was M. incognita (Figure 4.D-E), which were different to the molecular analysis results. The differences of species in morphological and molecular identification might be due to only the dominant species that appeared on molecular identification. Thus the morphological identification was carried out to identify the minor species singly.

The parameters used in the morphological identification were the shape of perennial pattern and the cuticle layer (striae). M. incognita has dorsally arch high and slim (Taher et al. 2012). Striae were very wavy and tight. $M$. javanica has oval till pear-shaped, smooth and less wavy of striae (Williams 1972), and have two lateral line as the key to distinguish with another species of Meloidogyne (Taher et al. 2012). The lateral lines divide the dorsal and ventral striae (Kaur et al. 2016). M. arenaria has oval till round shaped, and flat striae (Williams 1972). Dorsally arch short and slim (Taher et al. 2012). Both M. arenaria and M. javanica have low dorsal arch, whereas $M$. incognita has high dorsal arch (Aydinli and Mennan 2016).

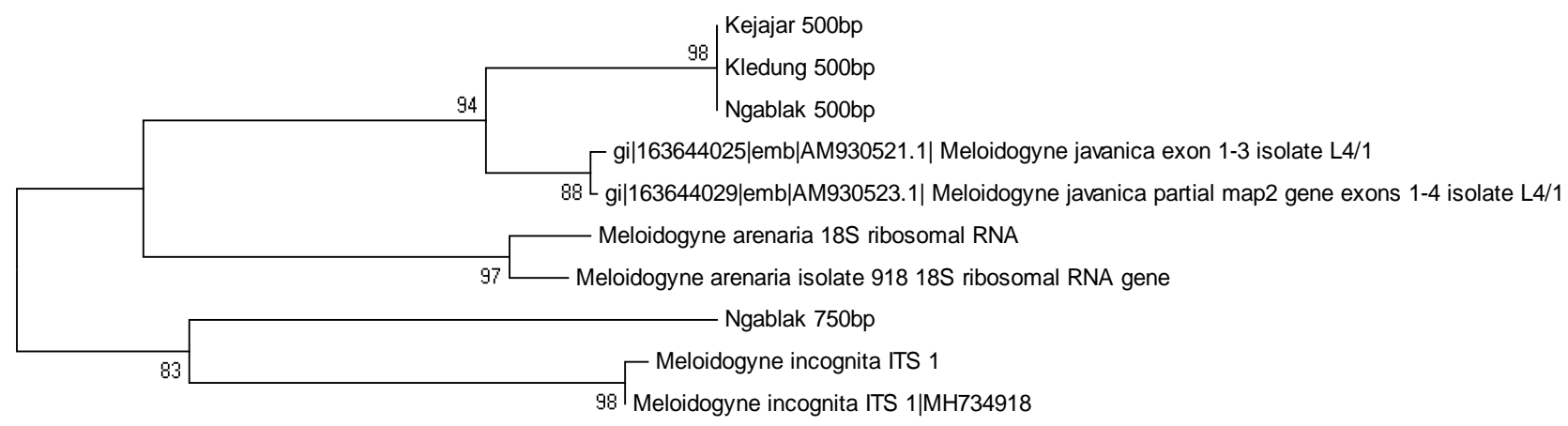

0.2

Figure 3. Phylogenetic tree of Meloidogyne spp. with neighbor joining method (MEGA 6.06) 


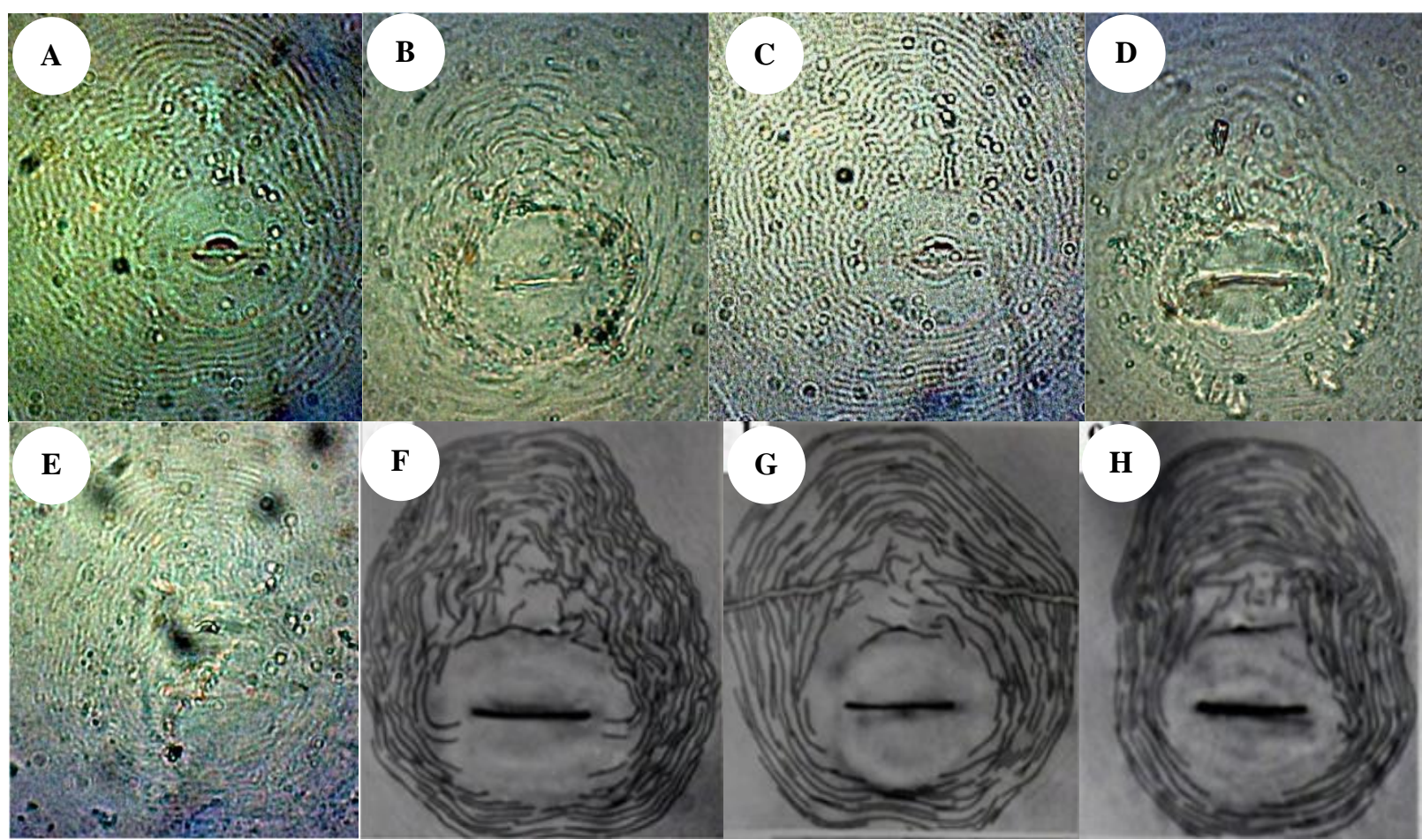

Figure 4. Perennial pattern of Meloidogyne spp.; A. Ngablak sample 1 (M. javanica), B. Ngablak sample 2 (M. incognita), C. Kejajar sample (M. arenaria), D-E. Kledung (M. incognita), F-H. M. incognita, M. javanica, M. arenaria (E-F: Eisenbeck et al. 1981)

In conclusions, the results of this survey showed that the prevalence infection was generally distributed in Central Java (35.71\%), dispersed in Ngablak (88.23\%), Kledung (62.5\%) and Kejajar (14.28\%). Species of Meloidogyne spp. which infect the potato center producing area in Central Java were $M$. incognita, $M$. javanica, and $M$. arenaria. These three species were the most destructive root-knot nematode in the tropical area. The Meloidogyne species found in this study are the common Meloidogyne spp. in the temperate region. This information is important to anticipate the wide distribution of the tuber infection and for nematode management strategy. The use of infectious tuber seed on the plantation should be prohibited moreover on the dry season harvesting. This was also in line with Evlice and Baryam (2016), conclude that unqualified potato seed tuber was forbidden to use in uninfected fields and must be followed by other management strategy to prevent the damage on potato tuber.

\section{REFERENCES}

Archidona-Yuste A, Cantalapiedra-Navarrete C, Liebanas G, Rapoport HF, Castillo P, Palomares-Rius JE. 2018. Diversity of root-knot nematodes of the genus Meloidogyne goeldi, 1892 (Nematoda: Meloidogynidae) associated with olive plants and environmental cues regarding their distribution in southern Spain. PLoS ONE. 13: e0198236. DOI: 10.1371/journal.pone.0198236.

Asif M, Rehman B, Parihar K, Ganai MA, Siddiqui MA. 2015. Effect of various physic-chemical factors on the incidence of root knot nematode Meloidogyne spp. infesting tomato in District Aligarh (Uttar Pradesh) India. Journal of Plant Sciences. 10: 234-243.
Aydinli G, Mennan S. 2016. Identification of root-knot nematodes (Meloidogyne spp.) from greenhouses in the Middle Black Sea Region of Turkey. Turkish J Zool 40: 675-685.

Bouwman LA, Arts WBM. 2001. Effects of soil compaction on the relationship between nematodes, grass production and soil physical properties. Appl Soil Ecol 14: 213-222

Bridge J, Starr JL. 2007. Plant Nematodes of Agricultural Importance. Manson Publishing Ltd, London.

Coyne DL, Cortada L, Dalzell JJ, Claudius-Cole AO, Haukeland S, Luambano N, Talwana H. 2018. Plant-parasitic nematodes and food security in Sub-Saharan Africa. Annual Review of Phytopathology. 56: 381-403.

Devi ML, Kumari MV. 2014. Prevalence of Meloidogyne species in different crops of Indian sub-continent-a review. International Journal of Advanced Research. 2: 533.

Eisenback JD, Hirschman H, JN. Sasser, AC. Triantaphyllou. 1981. A Guide to the Four Most Common Species of Root-Knot Nematodes (Meloidogyne spp.), with a Pictorial Key. North Carolina State University Graphics, Washington DC.

Eisenback JD. 1985. Diagnostic characters useful in the identification of four most common species of root-knot nematodes (Meloidogyne spp.). In: Sasser JN, Carter CC. (eds.). An Advanced Treatise on Meloidogyne. Volume I. Biology and Control. North Carolina State University Graphics, Raleigh, NC, USA.

Evlice E, Bayram S. 2016. Identification of root-knot nematode species (Meloidogyne spp.) (Nemata: Meloidogynidae) in the potato fields of Central Anatolia (Turkey) using molecular and morphological methods. Turkish bulletin of entomology. 6: 339-347.

Hay FS, Herdina, Ophel-Keller K, Hartley DM, Pethybridge SJ. 2016. Prediction of potato tuber damage by root-knot nematodes using Quantitative DNA Assay of Soil. Plant Disease. 100: 592-600.

$\mathrm{Hu}$ MX, Zhuo K, Liao JL. 2011. Multiplex PCR for simultaneous identification and detection of Meloidogyne incognita, M. enterolobii, and $M$. javanica using DNA extracted directly from individual galls. Nematology. 101: 1270-1277

Karajeh M, Mohawesh O. 2016. Root-knot nematode (Meloidogyne javanica)-deficit irrigation interactions on eggplant cropped under open field conditions. Journal of Horticultural Research. 24: 73-78. 
Kaur S, Kang SS, Dhillon NK, Sharma A. 2016. Detection and characterization of Meloidogyne species associated with pepper in Indian Punjab. Nematropica. 46: 209-220.

Kim E, Seo Y, Kim YS, Park Y, Kim YH. 2017. Effects of soil textures on infectivity of root-knot nematodes on carrot. Plant Pathology Journal. 33: 66-74.

Medina I, Gomes CB, Correa VR, Mattos VS, Sereno PC, Carneiro RMDG. 2017. Genetic diversity of Meloidogyne spp. parasitizing potato in Brazil and aggressiveness of $M$. javanica populations on susceptible cultivars. Nematology. 19: 69-80.

NAWASIS (National Water and Sanitation Information Services). 2010 Gambaran Umum Kabupaten Banjarnegara. Buku Putih Sanitas Kabupaten Banjarnegara. [Indonesian]

Netscher, C., and R. A. Sikora. 1990. Nematode parasites of vegetables. In: Luc M, Sikora RA, Bridge J (eds.). Plant Parasitic Nematodes in Subtropical and Tropical Agriculture. CAB International, Wallingford, Oxon, UK.

Oliveira CMG, Monteiro AR, Blok VC. 2011. Morphological and molecular diagnostics for plant-parasitic nematodes: working togethe to get the identification done. Tropical Plant Pathology. 36: 065-073.

Onkendi EM, Moleleki LN. 2013. Distribution and genetic diversity of root-knot nematodes (Meloidogyne spp.) in potatoes from South Africa. Plant Pathology. 62: 1184-1192.

Pemda Ngablak. 2015. Profil Kecamatan Ngablak. www.kecngablak.magelangkab.go.id. Date of accessed September, 22015 [Indonesian]

Pemkab Magelang. 2015. Kondisi geografis Kabupaten Magelang. www.magelangkab.go.id. Date of accessed September, 22015. [Indonesian]

Pemkab Temanggung. 2015. Kledung. www.temanggungkab.go.id. Date of accessed September, 2 2015. [Indonesian]

Pemkab Wonosobo. 2015. Kecamatan Kejajar. www.wonosobokab.go.id Date of accessed September, 2 2015. [Indonesian]

Perry RN, Moens M, Starr JL. 2009. Root-Knot Nematodes. MPG Books Group. UK.

Prot JC. 1977. Amplitude et cinetique des migrations de nematode Meloidogyne javanica sous l'influence d'un plant de tomate. Cahiers O. R. S. T. O. M. Serie Biologie 11: 157-166.
Qiu JJ, Westerdahi BB, Anderson C, Williamson VM. 2006. Sensitive PCR detection of Meloidogyne arenaria, M. incognita, dan $M$. javanica extracted from soil. Journal of Nematology. 38: 435-440.

Sawadogo A, Thio B, Kiemde S, Drabo I, Dabire C, Ouedraogo J, Mullens TR, Ehlers JD, Roberts PA. 2009. Distribution and prevalence of parasitic nematodes of cowpea (Vigna unguiculata) in Burkina Faso. Journal of Nematology. 41: 121.

Singh SK. 2009. Morphological and molecular characterization of rootknot nematode (Meloidogyne spp.) diversity in Fiji. [Thesis]. Faculty of Science, Technology, and Environment, The University of the South Pacific, Fiji.

Subandiyah S. 2003. Cara Kerja Ekstraksi DNA menggunakan CTAB. Workshop and training course on molecular detection for plant and environmental protection. Agriculture Faculty. Universitas Gadjah Mada, Yogyakarta. [Indonesian]

Suri F, Jayasinghe U. 2014. A survey of potato fields for root-knot nematode in Ngablak, Central Java. www.eseap.cipotato.org. Date of accessed December, 152014.

Taher M, Supramana, Suastika G. 2012. Identifikasi Meloidogyne penyebab penyakit umbi bercabang pada wortel di Dataran Tinggi Dieng. Jurnal Fitopatologi Indonesia. 8: 18-21. [Indonesian]

Vovlas N, Mifsud D, Landa BB, Castillo P. 2005. Phatogenicity of the root-knot nematode Meloidogyne javanica on potato. Plant Pathology. 54: 657-658.

Wesemael WML, Taning LM, Viaene N, Moens M. 2014. Life cycle and damage of the root-knot nematode Meloidogyne minor on potato, Solanum tuberosum. Nematology. 16: 185-192.

Williams KJO. 1972. Plant Parasitic Nematodes. Great Britian, London.

Ye W, Zeng Y, Kerns J. 2015. Molecular characterisation and diagnosis of root-knot nematodes (Meloidogyne spp.) from turfgrasses in North Carolina, USA. PLoS ONE. 10: e0143556.

Zijlstra C, Donkers-Venne DTHM., Fargette M. 2000. Identification of Meloidogyne incognita, $M$. javanica, and $M$. arenaria using sequence characterized amplified region (SCAR) based PCR assays. Nematology. 2: 847. 